\title{
THE PERCEPTION OF SMES BANKRUPTCY CONCERNING CSR IMPLEMENTATION
}

\author{
Zdenko Metzker \\ Tomas Bata University in Zlin, Faculty of Management and Economics, Zlin, Czech Republic \\ Email: metzker@utb.cz
}

Josef Maroušek

Faculty of Technology, Institute of Technology and Business in České Budějovice, České Budějovice, Czech Republic

Email: marousek@mail.vstecb.cz

Katarina Zvarikova

University of Zilina, Faculty of Operation and Economics of Transport and Communications, Zilina, Slovak Republic

Email: katarina.zvarikova@fpedas.uniza.sk

\section{Roman Hlawiczka}

Silesian University in Opava, School of Business Administration in Karviná, Karviná, Czech Republic E-mail: roman.hlawiczka@,opf.slu.cz

Received: 15 September 2021. Revision received: 4 November 2021. Accepted: 20 December 2021

\begin{abstract}
This study aims to evaluate the perception of bankruptcy by small and medium-sized enterprises from the V4 region. CSR implementation in business activities was selected as the comparison criterion. The research paper is based on a questionnaire survey of 1585 respondents. The data were collected from September 2019 to January 2020. The research hypotheses were evaluated using the $\chi$-quadrat test and Z-score statistical methods. Differences between the enterprises which implemented CSR in business and other companies were found. The research focused on bankruptcy perception as a natural part of the business and as a valuable experience for future company development. Entrepreneur failure and self-confidence showed that V4 SMEs with implemented CSR are less likely to go bankrupt if adverse economic developments occur. However, less than $50 \%$ of entrepreneurs consider bankruptcy as a valuable experience for further business. The majority of managers who have experience with CSR implementation positively differed in their opinions versus those without this experience. In general, V4 entrepreneurs who implemented CSR have a more positive perception of bankruptcy questions. The results may be interesting for those who promote or implement CSR in the focused countries. Our findings can be helpful for entrepreneurs to consider the benefits of being socially responsible in the working environment conception.
\end{abstract}

KEYWORDS: Corporate social responsibility, CSR impact on bankruptcy perception, small and medium-sized enterprises, business environment in the V4 countries, V4 SMEs segment.

\section{JEL CLASSIFICATION: M14, G33, L26}

Reference: Metzker, Z., Marousek, J., Zvarikova, K., Hlawiczka, R. (2021). The perception of SMEs bankruptcy concerning CSR implementation. International Journal of Entrepreneurial Knowledge, 9(2), 85-95. doi: 10.37335/ijek.v9i2.133

\section{INTRODUCTION}

Corporate social responsibility is currently a widely discussed topic with an increasing emphasis in the field of sustainable business development and the research focus of many scholars. Many published scientific papers reveal that socially responsible business is the domain of large companies with sufficient financial resources (Bhinekawati, 2018; Hörisch et al., 2015; Kumar et al., 2021; Zbuchea \& Pinzaru, 2017). Therefore many scholars deal with social responsibility focusing only on large companies. 


\section{INTERNATIONAL JOURNAL OF ENTREPRENEURIAL KNOWLEDGE}

Issue 9, volume 2, ISSN 2336-2960 (Online)

www.ijek.org

According to many authors, including Belas et al. (2021), Dvorský et al. (2020) and Zastempowski \& Cyfert (2021) SMEs are unique due to their high share of the economy, which has a positive effect on the country's GDP. The current trend of large companies is to use SMEs as strategic partners to produce selected products or services that SMEs supply to large companies (Rocha, 2012). In any case, it is important to implement it in SMEs as well, but this is a long-term process (Kljucnikov et al., 2016). CSR implemented in a corporation has a positive effect on consumer product perception, consumer loyalty, and brand image, which allows increasing the competitive advantage of the company (Al-Hadi et al., 2019; Pizzi et al., 2020; Qiu, Jiang, Liu, Chen, \& Yuan, 2021). Therefore authors are interested in investigating the CSR influence on sustainability and continuance of business activities (Dayanandan et al., 2018). Also, large companies need a different approach to CSR implementation than SMEs (Gelbmann, 2010).

The presented paper focuses on the corporate social responsibility of SMEs in the V4 countries from various aspects. It examines the perception of bankruptcy by SMEs managers in the case of CSR implementation into the company's praxis. Data were collected from September 2019 to April 2020via a questionnaire survey with a focus on management, business risks, and the bankruptcy of V4's SMEs.

\section{THEORETICAL REVIEW}

Corporate social responsibility has various interpretations and definitions. The responsibility of companies for their impact on society is defined as CSR by European Commission (2011), with the integration of social, environmental, ethical, consumer, and human rights aspects into businesses to maximalization of creating values for shareholders, stakeholders, and society, and also identifying, preventing and mitigating their possible adverse effects. Carrol (2016) defines 4 pillars of CSR, such as basic parts of conception: Economic responsibility - creating added value to bring stakeholders' benefints. Legal responsibility - doing business within the law and complying with the relevant legislative standards governing business. Ethical responsibility - expectation from corporations to society to do what is right and fair - companies adopt expected activities, standards and practices even if they are not clearly defined by legislation. Corporate philanthropy means a company's participation in the not expected activities of doing business with ethical sense for the whole society. The OECD offers a different definition: CSR as providing jobs, ensuring the goods and services produced to achieve consumer needs, and improving the population's living standards in the area of doing business - thus providing returns to shareholders.

According to some authors, a specific exact definition of CSR is missing today (Chojnacka \& Wiśniewska, 2016). Therefore CSR can be understood as a balanced management style taking into account the benefits of all stakeholders having regard to the risk and asset management (Hadj, 2019). This concept enables wealth distribution for stakeholders through ethical systems and sustainable management practices integration (Adda et al., 2016). Nowadays, CSR implementation is also useful to mitigate the negative impact on the environment from business activities (Al-Hadi et al., 2019; Belas et al., 2021; Carroll, 2016). Through CSR, businesses strive for a positive impact on the labour, social and natural environment and thanks to that gaining a competitive advantage in long-term sustainability (Sharma et al., 2021; Stojanovic et al., 2020; Zastempowski \& Cyfert, 2021). Implementation of CSR can improve brand prestige, stakeholders' satisfaction, and loyalty, thus increasing a company value and also is the best way to show charitable and environmental protection activities (Herrera Madueño et al., 2016; Lu et al., n.d.). Many studies are focused only on large enterprises. In V4 countries, CSR is a relative new concept with a rapid expanding trend, especially in multinational companies (Habek, 2017; Kljucnikov et al., 2016). The reasons for not implementing CSR in V4 are lack of knowledge and information about the area and lack of financial resources (Dvorský et al., 2020; Nagypal \& Noemi, 2014). 


\section{INTERNATIONAL JOURNAL OF ENTREPRENEURIAL KNOWLEDGE}

Issue 9, volume 2, ISSN 2336-2960 (Online)

www.ijek.org

SMEs are vulnerable to life-threatening bankruptcy (Rico et al., 2021). The results of several authors suggest that the likelihood of bankruptcy is notably affected by CSR. Thus, companies with better CSR performance are less likely to get bankrupt than companies without implemented CSR (Cooper \& Uzun, 2019; Kamalirezaei et al., 2020; Lin \& Dong, 2018a; Qiu, Jiang, Liu, Chen, Yuan, et al., 2021). There is currently very little research on the relationship between bankruptcy and CSR (Cooper \& Uzun, 2019). When comparing CSR and bankruptcy, we can start from Freeman's stakeholder theory, which suggests that it should be compatible with better financial performance (Freeman \& McVea, 2005). Stakeholder theory also suggests that companies which engage in CSR ultimately run a lower risk. Lu et al. support the idea that CSR can be effective management tool and companies as a strong representatives of social responsibility could have favourable investment and organizational strategies. Furthermore, stakeholder theory suggest that CSR activities are reducing the cost of capital (Dayanandan et al., 2018). Erragragui \& Elias (2018) found that environmental and governance strengths (part of CSR) reduce debt costs. Many companies implement CSR as the natural belief of a company's obligation beyond financial performance. Consistent with this argument is that successful firms have the resources to solve social issues and are perceived to do it with a greater extent than firms without the financial sources to do so (Cooper \& Uzun, 2019). Waddock \& Graves (2011) pay attention on a financial success that leads companies to become more involved in social issues which lead to achieve greater financial success. Ahn et al. (2018) concluded that determination of long-term enterprise survival is also caused by social responsibility. The scholars state that building social capital among primary stakeholders through CSR activities helps companies survive over time, while competition without mentioned links fails. Of course, the decisive factor in the impact of CSR on the likelihood of a bankruptcy is the size of the company. In the case of large companies, the impact of the CSR should be stronger on bankruptcy decisions (Cooper \& Uzun, 2019).

Several authors confirm from their own research that bankruptcy is a very important element in the subsequent success of an entrepreneur. If an entrepreneur is convinced that he must be omniscient, fully competent and able to achieve his goals, it means that is driven by the fear of failure. This fear will haunt businessman alongside his presence in the business environment. Entrepreneurs who are afraid think they are valuable only when they succeed. When they experience failures, they are considered worthless. They forget their past successes and, after failure, find it difficult to gain morale (Mariana \& Vasile, 2019). On the other hand, a large number of successes very often required a previous number of attempts and relative failures (Eklund et al., 2020). However, failure can occur for any entrepreneur, it represents a financial cost and psychological strain for the entrepreneur, his family, creditors and other stakeholders (Mariana \& Vasile, 2019). Addressing a corporate bankruptcy is, of course, very stressful for the entrepreneur himself. From a psychological point of view Jenkins (2021) found that most entrepreneurs experience relief and discovery after a business failure, while entrepreneurs who delay leaving their businesses after realizing they are failing are more likely to experience both. Entrepreneurs who were initially unable to cope with the failure resulting in the bankruptcy were more likely to be prepared in case of new opportunities exploration after the failure. On the other hand, the willingness in case of new opportunities discovering after failure may also reflect the high level of resilience which can be shown by entrepreneurs when they do not have to go through a recovery process until they are ready to take the new opportunities (Corner et al., 2017). One of the most difficult, complex and yet valuable experiences is entrepreneurs' failure. It can betray an entrepreneur's self-efficacy and naive optimism. Although failure can be a tough teacher, a business history consisting only of success can leads to overconfidence and unhealthy complacency (Cope, 2011). Jenkins (2021) adds that the entrepreneur's bankruptcy relief could be an important precursor how to learn from failure. It signals the entrepreneur's step back position from failure and it is expected that businessman begins the learning process from it. An important aspect in the process is focusing on personal growth after the company's bankruptcy, which signals the potential for entrepreneurs to go through the process of stress-related growth and build resilience for the future (Shepherd \& Williams, 2016). 
INTERNATIONAL JOURNAL OF ENTREPRENEURIAL KNOWLEDGE

Issue 9, volume 2, ISSN 2336-2960 (Online)

www.ijek.org

\section{AIM AND METHODOLOGICAL BASES}

The SMEs managers perceptions' of business bankruptcy in V4 countries is the aim of our research article. We examine the bankruptcy perception attributes from CSR point of view - by comparing respondents from V4 countries who implement CSR strategy into the company with other entrepreneurs, who are not doing business in responsible way. The basis of our research was a SME's questionnaire survey in which participated 368 Slovak, 364 Polish, 454 Czech, and 399 Hungarian representatives of SMEs managers. Data collection took place 6 months (from 09/2019 to 04/2020). 8250 Czech, 10100 Slovak, 7680 Polish and 8750 Hungarian SMEs were randomly selected. The average responses return rate was as followed: Czechia 3,6\%; Slovakia 5,5\%, Poland: 4,7\% and Hungary 4,6\%. The respondents sample is divided into individual V4 countries. In Czechia were involved $63.9 \%$ micro enterprises, 23.6\% small and $12.5 \%$ medium sized companies. $58.7 \%$ Slovak enterprises were micro sized, $28.8 \%$ small and $12.5 \%$ medium sized enterprises. In Poland were involved into questionnaire survey 55.5\% micro businesses, 23.3\% small and 21.2 medium sized enterprises. From Hungary 67.2\% micro, 18.3\% small and $14.5 \%$ medium sized enterprises attended the research.

The research article analyses entrepreneurs' attitudes to statements in bankruptcy relations (T1 to T5) in case of agreement with the statement I know the concept of corporate social responsibility (CSR) and promote it in my managerial practice.

- T1: The bankruptcy is a natural part of the business.

- T2: The bankruptcy of the company brings valuable experience for further business.

- T3: A bankruptcy does not mean an entrepreneur's failure.

- T4: Bankruptcy does not reduce the self-confidence of the entrepreneur.

- T5: Had your company ever gone thru bankruptcy? (Under bankruptcy we understand a crisis that has had a significant impact on the company's activities: bankruptcy, company reorganization, etc.?)

Respondents were able to express their opinions on individual claims by scoring on a following Likert scale: strongly agree, agree, disinterested, disagree, strongly disagree. Using statistical methods Z-score and $\chi$-quadrat test were tested statistically significant differences between researched groups.

Authors defined following hypotheses:

- H1: Statistically significant differences are existed in managers' attitudes towards T1 depending on implemented CSR.

- H2: Statistically significant differences are existed in managers' attitudes towards T2 depending on implemented CSR.

- H3: Statistically significant differences are existed in managers' attitudes towards T3 depending on implemented CSR.

- H4: Statistically significant differences are existed in managers' attitudes towards T4 depending on implemented CSR.

- H5: Statistically significant differences are existed in managers' attitudes towards T5 depending on implemented CSR.

\section{RESULTS AND DISCUSSION}

\section{The bankruptcy is a natural part of the business.}

Table 1 The structure of answers to hypothesis $\mathbf{H} 1$ 
INTERNATIONAL JOURNAL OF ENTREPRENEURIAL KNOWLEDGE

Issue 9, volume 2, ISSN 2336-2960 (Online)

www.ijek.org

\begin{tabular}{|c|c|c|c|c|c|c|}
\hline \multirow[t]{2}{*}{ T1 } & \multicolumn{2}{|c|}{$\begin{array}{c}\text { CSR } \\
\text { enterprises }\end{array}$} & \multicolumn{2}{|c|}{$\begin{array}{c}\text { Non CSR } \\
\text { enterprises }\end{array}$} & \multirow[t]{2}{*}{ Z-score } & \multirow{2}{*}{$\begin{array}{l}\text { Z-score } \\
\text { p-value }\end{array}$} \\
\hline & No. & $\%$ & No. & $\%$ & & \\
\hline strongly agree + agree & 300 & 34,88 & 227 & 31,31 & 1,5044 & 0,1336 \\
\hline disinterested & 214 & 24,88 & 235 & 32,41 & $-3,3145$ & 0,0009 \\
\hline disagree + strongly disagree & 346 & 40,23 & 263 & 36,28 & 1,6134 & 0,1074 \\
\hline$\chi$-quadrat & \multicolumn{2}{|c|}{10,9874} & \multirow{2}{*}{\multicolumn{2}{|c|}{$a=0.05$}} & & \\
\hline$\chi$-quadrat $p$-value & \multicolumn{2}{|c|}{0,0041} & & & & \\
\hline
\end{tabular}

(Source: own data collection)

Almost $35 \%$ of socially responsible entrepreneurs (CSR + ) answered the question bankruptcy is a natural part of the business. The manager of companies that do not have social responsibility implemented in their practice (CSR-) responded similarly. We noticed significant differences in disinterested responses. Here, up to $32.4 \%$ of CSR entrepreneurs are not interested. In terms of different answers, CSR + entrepreneurs have larger dissenting answers. Thus, they no longer agree with the statement that the bankruptcy of a company is a natural part of business. This is also related to the very mission of social responsibility, specifically economic responsibility (Carrol, 2016). Based on statistical calculations, we claim that there are statistically significant differences between the V4 SMEs in terms of the implementation of CSR in the T1 statement context. Hypothesis H1 is accepted.

The bankruptcy of the company brings valuable experience for further business

Table 2 The structure of answers to hypothesis $\mathbf{H} 2$

\begin{tabular}{|c|c|c|c|c|c|c|}
\hline \multirow[t]{2}{*}{$\mathrm{T} 2$} & \multicolumn{2}{|c|}{$\begin{array}{c}\text { CSR } \\
\text { enterprises }\end{array}$} & \multicolumn{2}{|c|}{$\begin{array}{c}\text { Non CSR } \\
\text { enterprises }\end{array}$} & \multirow[t]{2}{*}{ Z-score } & \multirow{2}{*}{$\begin{array}{l}\text { Z-score } \\
\text { p-value }\end{array}$} \\
\hline & No. & $\%$ & No. & $\%$ & & \\
\hline strongly agree + agree & 413 & 48,02 & 319 & 44,00 & 1,6006 & 0,1096 \\
\hline disinterested & 235 & 27,33 & 219 & 30,21 & $-1,2641$ & 0,2077 \\
\hline disagree + strongly disagree & 212 & 24,65 & 187 & 25,79 & $-0,5219$ & 0,6031 \\
\hline \multirow{2}{*}{$\begin{array}{c}\chi \text {-quadrat } \\
\chi \text {-quadrat } p \text {-value }\end{array}$} & \multicolumn{2}{|c|}{2,7227} & \multirow{2}{*}{\multicolumn{2}{|c|}{$a=0.05$}} & & \\
\hline & \multicolumn{2}{|c|}{0,2563} & & & & \\
\hline
\end{tabular}

(Source: own data collection)

According to $44 \%$ of CSR entrepreneurs, corporate bankruptcy is a valuable experience for future business. Only 4\% more CSR + managers agree with this statement. This means that managers are aware that every bankruptcy is caused by some cause. Identifying it in the future - learning from your previous mistakes can make a positive contribution to corporate management. The dissenting responses between the parties examined are almost identical. We found that there are no statistically significant differences between SME entrepreneurs using CSR and others in the V4 countries. We reject hypothesis H2.

A bankruptcy does not mean an entrepreneur's failure.

Table 3 The structure of answers to hypothesis $\mathbf{H 3}$

\begin{tabular}{|c|c|c|c|c|}
\hline T3 & $\begin{array}{c}\text { CSR } \\
\text { enterprises }\end{array}$ & $\begin{array}{c}\text { Non CSR } \\
\text { enterprises }\end{array}$ & Z-score & Z-score \\
\hline & No. $\quad \%$ & No. $\quad \%$ & & \\
\hline
\end{tabular}


INTERNATIONAL JOURNAL OF ENTREPRENEURIAL KNOWLEDGE

Issue 9, volume 2, ISSN 2336-2960 (Online)

www.ijek.org

\begin{tabular}{|c|c|c|c|c|c|c|}
\hline strongly agree + agree & 335 & 38,95 & 246 & 33,93 & 2,0673 & 0,0385 \\
\hline disinterested & 237 & 27,56 & 240 & 33,10 & $-2,3979$ & 0,0164 \\
\hline disagree + strongly disagree & 288 & 33,49 & 239 & 32,97 & 0,2201 & 0,8259 \\
\hline \multirow{2}{*}{$\begin{array}{c}\chi \text {-quadrat } \\
\chi \text {-quadrat } p \text {-value }\end{array}$} & \multicolumn{2}{|c|}{6,7588} & \multirow{2}{*}{\multicolumn{2}{|c|}{$a=0.05$}} & & \\
\hline & \multicolumn{2}{|c|}{0,0341} & & & & \\
\hline
\end{tabular}

(Source: own data collection)

CSR- entrepreneurs' answers to the question bankruptcy does not mean an entrepreneur's failure are almost the same - divided into thirds. At the same time, there are statistically significant differences in the agreed answers and disinterested possibilities between the examined groups of entrepreneurs. We accept hypothesis $\mathrm{H} 3$ - there are statistically significant differences in T3's statement in case of sample groups comparison.

Bankruptcy does not reduce the self-confidence of the entrepreneur.

Table 4 The structure of answers to hypothesis $\mathbf{H} 4$

\begin{tabular}{|c|c|c|c|c|c|c|}
\hline \multirow[t]{2}{*}{$\mathbf{T} 4$} & \multicolumn{2}{|c|}{$\begin{array}{c}\text { CSR } \\
\text { enterprises }\end{array}$} & \multicolumn{2}{|c|}{$\begin{array}{c}\text { Non CSR } \\
\text { enterprises }\end{array}$} & \multirow[t]{2}{*}{ Z-score } & \multirow{2}{*}{$\begin{array}{l}\text { Z-score } \\
\text { p-value }\end{array}$} \\
\hline & No. & $\%$ & No. & $\%$ & & \\
\hline strongly agree + agree & 185 & 21,51 & 119 & 16,41 & 2,5681 & 0,0102 \\
\hline disinterested & 213 & 24,77 & 205 & 28,28 & $-1,5791$ & 0,1141 \\
\hline disagree + strongly disagree & 462 & 53,72 & 401 & 55,31 & 0,6330 & 0,5287 \\
\hline \multirow{2}{*}{$\begin{array}{c}\chi \chi \text {-quadrat } \\
\chi \text {-quadrat } p \text {-value }\end{array}$} & \multicolumn{2}{|c|}{7,3486} & \multirow{2}{*}{\multicolumn{2}{|c|}{$a=0.05$}} & & \\
\hline & & 254 & & & & \\
\hline
\end{tabular}

(Source: own data collection)

In claim bankruptcy does not reduce the self-confidence of the entrepreneur, a statistically significant difference is evident in the affirmative responses. In this case, we see 5\% differences between CSR + and other V4 SMEs. More than $50 \%$ of respondents disagree with this statement and at the same time almost $25 \%$ of CSR + and almost $29 \%$ of other managers are disinterested. This means in most cases that respondents confirm corporate bankruptcy reduces the entrepreneur's self-confidence. The values of the $\chi$-quadrat test show that there are statistically significant differences in the T4 statement. Therefore we accept hypothesis $\mathrm{H} 4$.

Had your company ever gone thru bankruptcy? (Under bankruptcy we understand a crisis that has had a significant impact on the company's activities: bankruptcy, company reorganization, etc.?).

Table 5 The structure of answers to hypothesis $\mathbf{H 5}$

\begin{tabular}{|c|c|c|c|c|c|c|}
\hline \multirow[t]{2}{*}{ T5 } & \multicolumn{2}{|c|}{$\begin{array}{c}\text { CSR } \\
\text { enterprises }\end{array}$} & \multicolumn{2}{|c|}{$\begin{array}{c}\text { Non CSR } \\
\text { enterprises }\end{array}$} & \multirow[t]{2}{*}{ Z-score } & \multirow{2}{*}{$\begin{array}{l}\text { Z-score } \\
\text { p-value }\end{array}$} \\
\hline & No. & $\%$ & No. & $\%$ & & \\
\hline YES & 99 & 11,51 & 111 & 15,31 & $-2,2223$ & 0,0264 \\
\hline $\mathrm{NO}$ & 761 & 88,49 & 614 & 84,69 & 2,2223 & 0,0264 \\
\hline \multirow{2}{*}{$\begin{array}{c}\chi \text {-quadrat } \\
\chi \text {-quadrat p-value }\end{array}$} & \multicolumn{2}{|c|}{4,9388} & \multirow{2}{*}{\multicolumn{2}{|c|}{$a=0.05$}} & & \\
\hline & \multicolumn{2}{|c|}{0,0263} & & & & \\
\hline
\end{tabular}




\section{INTERNATIONAL JOURNAL OF ENTREPRENEURIAL KNOWLEDGE}

Issue 9, volume 2, ISSN 2336-2960 (Online)

www.ijek.org

\section{(Source: own data collection)}

At the end of the research questions, the authors investigated whether SMEs had gone through bankruptcies. $11.5 \%$ of CSR + and up to $15.3 \%$ of other companies during their existence had to deal with pitfalls that had a significant impact on corporate activities. We accept hypothesis H5 because there are statistically significant differences between the selection groups on the issue of bankruptcy situation in enterprise practice.

In comparison with other studies (e.g., Cooper \& Uzun, 2019), we confirmed that V4 SMEs with implemented CSR conception have a lower number of companies that went through bankruptcy than businesses without acting responsibly. If bankruptcy is a natural part of the business, we did not notice significant differences between CSR + and other entrepreneurs with positive answers to this statement. We can generalize that more than $30 \%$ of managers surveyed consider bankruptcy a natural part of a business's "life cycle." Statement is confirmed by Lin \& Dong (2018) or Cooper \& Uzun (2019).

Comparing the impact of CSR on the perception of bankruptcy as a valuable experience of the entrepreneur, there are no significant rules that CSR would dramatically affect the attitude of managers to this statement. $44 \%$ of CSR-entrepreneurs and at the same time, more than $48 \%$ of CSR + managers agree with this statement. Our knowledge that bankruptcy is a valuable business experience supports e. g. Collett et al. (2014), Rico et al. (2021), Schweizer \& Nienhaus (2017) and others.

Inquiries that do not implement CSR in management practice have almost the same distribution of responses to the statement: bankruptcy does not mean an entrepreneur's failure. If we focus on CSR+ entrepreneurs, up to $38 \%$ agree with this statement - there is a statistically significant deviation in the case of positive answers. Therefore, we can say that our research has shown that in the V4 countries, entrepreneurs implementing CSR perceive a more positive aspect that enterprise bankruptcy is not a personal failure of the entrepreneur (Mariana \& Vasile, 2019; Eklund et al., 2020). A similar analogy between CSR + and other entrepreneurs is also significant in the differences in the perception of the claim that bankruptcy does not reduce the self-confidence of the entrepreneur. Entrepreneurs who do not implement CSR are more critical in evaluating the questions. Only 16.5\% of respondents agree that bankruptcy does not reduce self-confidence. In the case of CSR + , it is more than $21 \%$. However, more than $50 \%$ of people in business disagree with the statement. Research has shown that entrepreneurs in the V4 countries do not agree that the bankruptcy of a company does not reduce the self-confidence of an entrepreneur. This statement is supported by e. g. Drover et al. (2014), Jenkins (2021) \& Byrne \& Shepherd (2015) discovered that bankruptcy declines an entrepreneur's confidence and increases stress emotions.

At the same time, we support Lin \& Dong (2018), Sun \& Cui (2014), Kamalirezaei et al. (2020), who claim that entrepreneurs (in our case SMEs in V4 countries) implementing CSR in their business activities are less likely to go bankrupt in the event of unfavorable economic developments because they have committed to conducting responsible business (in the context of economic responsibility). Therefore, CSR enterprises also provide a higher probability of a faster recovery from adverse situations.

The study's limitation is in comparing managers' perception of bankruptcy only at the level of implementing CSR in SMEs. However, comparing our results following other criteria, such as countries, business sector, etc., can expand knowledge and issue an opinion on CSR's positive impact, especially for V4 SMEs.

\section{CONCLUSION}




\section{INTERNATIONAL JOURNAL OF ENTREPRENEURIAL KNOWLEDGE}

Issue 9, volume 2, ISSN 2336-2960 (Online)

www.ijek.org

Our research article aimed to determine the SMEs managers' perception of bankruptcy concerning corporate social responsibility implementation in the companies in the V4 countries. In most cases, statistically significant differences were found.

This paper showed that V4 SMEs with implemented CSR are less likely to go bankrupt if adverse economic developments occur. The issue of bankruptcy as a natural part of the business lifecycle is more supported by the managers with CSR implementation experience than by those who did not implement CSR in their company. Less than 50\% of entrepreneurs consider bankruptcy a valuable experience for further business. Managers with CSR implementation experience have a significantly more positive relation to the statement that bankruptcy does not mean an entrepreneur failure. Only a few respondents agreed with the statement that bankruptcy does not reduce entrepreneurs' self-confidence. Also, there were significant differences between CSR + and other entrepreneurs with a positive opinion about CSR. In general, V4 entrepreneurs who implemented CSR into their companies' practice have a more positive perception of bankruptcy questions.

Bankruptcy perception's comparison limits our study only at the level of implemented CSR in enterprises. We cannot generalize the results because we performed the research only in V4 countries. Future research could deal with the bankruptcy issue more complexly. This study can be seen as a starting point for future research on a widespread sample impacting other countries than V4. Future comparisons could expand knowledge in the field of bankruptcy and CSR. The paper's results may be interesting for those who promote the implementation of CSR in the focused countries. The study can further help other entrepreneurs to gain the benefits of doing socially responsible entrepreneurship.

\section{ABBREVIATIONS}

SME: Small and medium-sized enterprises

CSR+: companies with implemented concept CSR in practice

CSR-: companies without CSR implementation in practice

\section{REFERENCES}

Adda, G., Bosco Azigwe, J., \& Awuni, A. R. (2016). BUSINESS ETHICS AND CORPORATE SOCIAL RESPONSIBILITY FOR BUSINESS SUCCESS AND GROWTH. European Journal of Business and Innovation Research, 4(6), 26-42. www.eajournals.org

Ahn, S.-Y., Park, D.-J., Ahn, S.-Y., \& Park, D.-J. (2018). Corporate Social Responsibility and Corporate Longevity: The Mediating Role of Social Capital and Moral Legitimacy in Korea. Journal of Business Ethics, 150(1), 117-134. https://doi.org/10.1007/S10551-016-3161-3

Al-Hadi, A., Chatterjee, B., Yaftian, A., Taylor, G., \& Monzur Hasan, M. (2019). Corporate social responsibility performance, financial distress and firm life cycle: evidence from Australia. Accounting and Finance, 59(2), 961-989. https://doi.org/10.1111/ACFI.12277

Belas, J., Çera, G., Dvorský, J., \& Cepel, M. (2021). Corporate social responsibility and sustainability issues of small- and medium-sized enterprises. Corporate Social Responsibility and Environmental Management, 28(2), 721-730. https://doi.org/10.1002/CSR.2083

Bhinekawati, R. (2018). A Model of a Large Company's CSR and Transformational Community Engagement Strategy for SME Development. ASEAN Journal of Community Engagement, 2(2), 200. https://doi.org/10.7454/AJCE.V2I2.130

Byrne, O., \& Shepherd, D. A. (2015). Different Strokes for Different Folks: Entrepreneurial Narratives of Emotion, Cognition, and Making Sense of Business Failure. Entrepreneurship Theory and Practice, 39(2), 375-405. https://doi.org/10.1111/etap.12046

Carroll, A. B. (2016). Carroll's pyramid of CSR: taking another look. International Journal of Corporate Social Responsibility 2016 1:1, 1(1), 1-8. https://doi.org/10.1186/S40991-016-0004-6 


\section{INTERNATIONAL JOURNAL OF ENTREPRENEURIAL KNOWLEDGE}

Issue 9, volume 2, ISSN 2336-2960 (Online)

www.ijek.org

Chojnacka, E., \& Wiśniewska, J. (2016). Benefits of Corporate Social Responsibility Engagement in Companies: The Case of Poland. Journal of Management and Business Administration. Central Europe, 24(4), 25-48. https://doi.org/10.7206/JMBA.CE.2450-7814.181

Collett, N., Pandit, N. R., \& Saarikko, J. (2014). Success and failure in turnaround attempts. An analysis of SMEs within the Finnish Restructuring of Enterprises Act. Entrepreneurship \& Regional Development, 26(1-2), 123-141. https://doi.org/10.1080/08985626.2013.870236

Cooper, E., \& Uzun, H. (2019). Corporate social responsibility and bankruptcy. Studies in Economics and Finance, 36(2), 130-153. https://doi.org/10.1108/SEF-01-2018-0013

Cope, J. (2011). Entrepreneurial learning from failure: An interpretative phenomenological analysis. Journal of Business Venturing, 26(6), 604-623. https://doi.org/10.1016/J.JBUSVENT.2010.06.002

Corner, P. D., Singh, S., \& Pavlovich, K. (2017). Entrepreneurial resilience and venture failure: Http://Dx.Doi.Org/10.1177/0266242616685604, 35(6), 687-708. https://doi.org/10.1177/0266242616685604

Dayanandan, A., Donker, H., \& Nofsinger, J. (2018). Corporate goodness and profit warnings. Review of Quantitative Finance and Accounting, 51(2), 553-573. https://doi.org/10.1007/s11156-017-0680-7

Drover, W., Wood, M. S., \& Fassin, Y. (2014). Take the money or run? Investors' ethical reputation and entrepreneurs' willingness to partner. Journal of Business Venturing, 29(6), 723-740. https://doi.org/10.1016/j.jbusvent.2013.08.004

Dvorský, J., Kljucnikov, A., \& Polách, J. (2020). Business risks and their impact on business future concerning the entrepreneur's experience with business bankruptcy: Case of Czech Republic. Problems and Perspectives in Management, 18(2), 418-430. https://doi.org/10.21511/ppm.18(2).2020.34

Eklund, J., Levratto, N., \& Ramello, G. B. (2020). Entrepreneurship and failure: two sides of the same coin? Small Business Economics, 54(2), 373-382. https://doi.org/10.1007/s11187-018-0039-z

Erragragui, \& Elias. (2018). Do creditors price firms' environmental, social and governance risks? Research in International Business and Finance, 45(C), 197-207. https:// doi.org/10.1016/J.RIBAF.2017.07.151

European Union. (2011). Communication from the Commission to the European Parliament, the Council, the European Economic and Social Committee and the Committee of the Regions - A renewed EU Strategy for Corporate Social Responsibility 2011-2014.

Freeman, R. E. E., \& McVea, J. (2005). A Stakeholder Approach to Strategic Management. SSRN Electronic Journal. https://doi.org/10.2139/SSRN.263511

Gelbmann, U. (2010). Establishing strategic CSR in SMEs: an Austrian CSR quality seal to substantiate the strategic CSR performance. Sustainable Development, 18(2), 90-98. https://doi.org/10.1002/SD.448

Habek, P. (2017). CSR Reporting Practices in Visegrad Group Countries and the Quality of Disclosure. Sustainability 2017, Vol. 9, Page 2322, 9(12), 2322. https://doi.org/10.3390/SU9122322

Hadj, T. B. (2019). Effects of corporate social responsibility towards stakeholders and environmental management on responsible innovation and competitiveness. https://doi.org/10.1016/j.jclepro.2019.119490

Herrera Madueño, J., Larrán Jorge, M., Martínez Conesa, I., \& Martínez-Martínez, D. (2016). Relationship between corporate social responsibility and competitive performance in Spanish SMEs: Empirical evidence from a stakeholders' perspective. BRQ Business Research Quarterly, 19(1), 55-72. https://doi.org/10.1016/j.brq.2015.06.002

Hörisch, J., Johnson, M. P., \& Schaltegger, S. (2015). Implementation of Sustainability Management and Company Size: A Knowledge-Based View. Business Strategy and the Environment, 24(8), 765-779. https://doi.org/10.1002/BSE.1844

Jenkins, A. S. (2021). Relief and exploration after firm failure: Taking into account pre-failure experiences to understand post-failure responses. Journal of Business Venturing Insights, 15(October 2020), e00226. https://doi.org/10.1016/j.jbvi.2021.e00226

Kamalirezaei, H., Anvary Rostamy, A. A., Saeedi, A., \& Khodaei Valeh Zaghard, M. (2020). Corporate social responsibility and bankruptcy probability: Exploring the role of market competition, intellectual capital, and equity cost. Journal of Corporate Accounting \& Finance, 31(1), 53-63. 


\section{INTERNATIONAL JOURNAL OF ENTREPRENEURIAL KNOWLEDGE}

Issue 9, volume 2, ISSN 2336-2960 (Online)

www.ijek.org

https://doi.org/10.1002/JCAF.22417/FORMAT/PDF

Kljucnikov, A., Belas, J., Kozubikova, L., \& Pasekova, P. (2016). The Entreprenurial Perception of SME Business Environment Quality in the Czech Republic. Journal of Competitiveness, 8(1), 66-78. https://doi.org/10.7441/JOC.2016.01.05

Kumar, K., Batra, R., \& Boesso, G. (2021). Difference in stakeholder engagement approach of small \& medium enterprises and large companies and its performance implications. Corporate Social Responsibility and Environmental Management, 28(3), 992-1001. https://doi.org/10.1002/CSR.2100/FORMAT/PDF

Lin, K. C., \& Dong, X. (2018). Corporate social responsibility engagement of financially distressed firms and their bankruptcy likelihood. https://doi.org/10.1016/j.adiac.2018.08.001

Lu, J., Ren, L., Zhang, C., Wang, C., Shahid, Z., \& Streimikis, J. (n.d.). THE INFLUENCE OF A FIRM'S CSR INITLATIVES ON BRAND LOYALTY AND BRAND IMAGE. https://doi.org/10.7441/joc.2020.02.07

Mariana, C., \& Vasile, E. N. E. (2019). A behavioral model of failure in business. XXVT(3), 151-158.

Nagypal, C., \& Noemi. (2014). Corporate social responsibility of Hungarian SMEs with good environmental practices. Journal of East European Management Studies, 19(3), 327-347. https://doi.org/10.5771/0949-6181-2014-3-327

OECD. (2001). Corporate responsibility: private initiatives and public goals. In Mexico Hungary Korea.

Pizzi, S., Caputo, F., \& Venturelli, A. (2020). Does it pay to be an honest entrepreneur? Addressing the relationship between sustainable development and bankruptcy risk. Corporate Social Responsibility and Environmental Management, 27(3), 1478-1486. https://doi.org/10.1002/CSR.1901

Qiu, S. (Charles), Jiang, J., Liu, X., Chen, M. H., \& Yuan, X. (2021). Can corporate social responsibility protect firm value during the COVID-19 pandemic? International Journal of Hospitality Management, 93(November 2020), 102759. https:// doi.org/10.1016/j.ijhm.2020.102759

Qiu, S. (Charles), Jiang, J., Liu, X., Chen, M. H., Yuan, X., Yoon, B., Chung, Y., Palacios-Manzano, M., Gras-Gil, E., Santos-Jaen, J. M., Sharma, R. B., Sharma, A., Ali, S., Dadhich, J., Ziogas, I., Metaxas, T., Barrena-Martinez, J., López-Fernández, M., Romero-Fernandez, P. M., ... Diaz-Carrion, R. (2021). Employee happiness and corporate social responsibility: the role of organizational culture. Sustainability (Switzerland), 43(3), 89-96. https://doi.org/10.1108/ER-07-2020-0343

Rico, M., Pandit, N. R., \& Puig, F. (2021). SME insolvency, bankruptcy, and survival: an examination of retrenchment strategies. Small Business Economics, 57(1), 111-126. https://doi.org/10.1007/s11187019-00293-z

Rocha, E. A. G. (2012). The Impact of the Business Environment on the Size of the Micro, Small and Medium Enterprise Sector; Preliminary Findings from a Cross-Country Comparison. Procedia Economics and Finance, 4(Icsmed), 335-349. https://doi.org/10.1016/s2212-5671(12)00348-6

Schweizer, L., \& Nienhaus, A. (2017). Corporate distress and turnaround: integrating the literature and directing future research. Business Research, 10(1), 3-47. https://doi.org/10.1007/s40685-016-00418

Sharma, R. B., Sharma, A., Ali, S., \& Dadhich, J. (2021). Corporate social responsibility and financial performance: Evidence from manufacturing and service industry. Academic Journal of Interdisciplinary Studies, 10(3), 301-307. https://doi.org/10.36941/AJIS-2021-0085

Shepherd, D. A., \& Williams, T. A. (2016). Hitting Rock Bottom After Job Loss: Bouncing Back to Create a New Positive Work Identity. Https://Doi.Org/10.5465/Amr.2015.0102, 43(1), 28-49. https://doi.org/10.5465/AMR.2015.0102

Stojanovic, A., Milosevic, I., Arsic, S., Urosevic, S., \& Mihajlovic, I. (2020). Corporate social responsibility as a determinant of employee loyalty and business performance. Journal of Competitiveness, 12(2), 149166. https://doi.org/10.7441/JOC.2020.02.09

Sun, W., \& Cui, K. (2014). Linking corporate social responsibility to firm default risk. European Management Journal, 32(2), 275-287. https://doi.org/10.1016/j.emj.2013.04.003

Waddock, S. A., \& Graves, S. B. (2011). The Corporate Social Performance-Financial Performance Link Author ( s ): Sandra A. Waddock and Samuel B. Graves Published by: Wiley Stable URL: 
INTERNATIONAL JOURNAL OF ENTREPRENEURIAL KNOWLEDGE

Issue 9, volume 2, ISSN 2336-2960 (Online)

www.ijek.org

http://www.jstor.org/stable/3088143 REFERENCES Linked references are available on JSTOR for this article: Strategic Management Journal, 18(4), 303-319.

Zastempowski, M., \& Cyfert, S. (2021). Social responsibility of SMEs from the perspective of their innovativeness: Evidence from Poland. Journal of Cleaner Production, 317. https://doi.org/10.1016/J.JCLEPRO.2021.128400

ZBUCHEA, A., \& PINZARU, F. (2017). Tailoring CSR Strategy to Company Size? Management Dynamics in the Knowledge Economy, 5(3), 415-437. https://doi.org/10.25019/MDKE/5.3.06

\section{ACKNOWLEDGMENT}

This paper is supported by Tomas Bata University in Zlin through; IGA/FaME/2021/005. Significant factors in the sustainability of economic growth with a focus on the SME segment.

\section{BRIEF DESCRIPTION OF AUTHOR/AUTHORS:}

\section{Ing. Zdenko Metzker}

ORCID ID: https://orcid.org/0000-0002-6962-2428

Ph.D. student in Centre of Applied Economics Research, Faculty of Management and Economics Thomas Bata University in Zlin, Mostni 5139, Zlin, Czech Republic, e-mail: metzker@utb.cz. His research field is focused on Corporate social responsibility in small and medium-sized enterprises segment.

doc. Ing. Josef Maroušek, Ph.D.

ORCID ID: https://orcid.org/0000-0001-5175-1961

Associate. professor at the Faculty of Technology, Institute of Technology and Business in České Budějovice, České Budějovice, Czech Republic. Email: marousek@mail.vstecb.cz. His research field is focused on Corporate social responsibility and sustainable development of enterprises.

\section{Ing. Katarina Zvarikova, PhD.}

ORCID ID: https://orcid.org/0000-0001-5278-9275

Associate. professor at the Department of Economics, Faculty of Operation and Economics of Transport and Communications, Univerzitna 8215/1, University of Zilina. Her research activities focus mainly on applying methods in the financial management and decision-making process of companies, risk quantification and analysis, quantitative mathematical, statistical methods in the company's financial management.

\section{Ing. Roman Hlawiczka, Ph.D.}

ORCID ID: https://orcid.org/0000-0002-6429-2095

Assistent at Silesian University in Opava, School of Business Administration in Karviná, Department of Finance and Accounting, Univerzitní náměstí 1934/3, 73340 Karviná, Czech Republic, E-mail: roman.hlawiczka@opf.slu.cz. His scientific activities are concentrated on business administration, financing of enterprises, and financial services. 